\title{
NEW NON-INVASIVE APPROACHES TO THE DIAGNOSIS OF LYMPH NODE METASTASES FROM BREAST CANCER BY MASS SPECTROMETRY
}

Tokareva $\mathrm{AO}^{1,2}$, Chagovets $\mathrm{W}^{1}$, Rodionov $\mathrm{W}^{1}$, Kometova $\mathrm{W}^{1}$, Rodionova MV ${ }^{1}$, Starodubtseva $\mathrm{NL}^{1,2}$, Frankevich VE ${ }^{1 凶}$

${ }^{1}$ Kulakov National Medical Research Center for Obstetrics, Gynecology and Perinatology, Moscow, Russia

2 V. L. Talrose Institute for Energy Problems of Chemical Physics, Moscow, Russia

\begin{abstract}
Early diagnosis of metastasis makes it possible to select the optimal treatment protocol and improve patient survival. Noninvasive and minimally invasive diagnostic techniques help to make a diagnosis with minimal damage to the body. The study was aimed to find biomarkers, being the hallmarks of the metastatic process initiation, and to develop a diagnostic model based on the plasma lipid profile using liquid chromatography-mass spectrometry. We studied blood plasma of 55 patients, 28 of them were diagnosed with the regional lymph node metastasis; the control group comprised 27 patients. The levels of lipids, belonging to the groups, such as oxidized lipids and sphingomyelins, in patients with metastases were significantly higher and significantly lower, respectively. The lipid panels were created by multivariate analysis, and the models based on these panels showed sensitivity and specificity of 79 and $74 \%$ (positive ion mode), and of 50 and $85 \%$ (negative ion mode) in leave-one-out cross-validation.
\end{abstract}

Keywords: lipids, regional metastasis, breast cancer, blood plasma, molecular markers

Funding: the study was funded by RFBR and National Natural Science Foundation of China within the framework of the scientific project № 19-515-55021

Compliance with ethical standards: the study was approved by the Ethics Committee of Kulakov National Medical Research Center for Obstetrics, Gynecology and Perinatology (protocol № 9 dated November 22, 2018); the study was carried out in accordance with the requirements of the Declaration of Helsinki, International Council for Harmonisation (ICF), Good Clinical Practice (GCP) guidelines, Federal Law 323-FZ dated November 21, 2011 "On the Basics of Protecting the Health of Citizens in the Russian Federation"; the informed consent was submitted by all patients.

$\triangle$ Correspondence should be addressed: Vladimir E. Frankevich Oparina, 4, Moscow, 117997, Russia; vfrankevich@gmail.com

Received: 26.10.2021 Accepted: 08.11.2021 Published online: 10.11.2021

DOI: $10.24075 /$ brsmu.2021.053

\section{НОВЫЕ НЕИНВАЗИВНЫЕ ПОДХОДЫ К ДИАГНОСТИКЕ МЕТАСТАТИЧЕСКОГО ПОРАЖЕНИЯ ЛИМФОУЗЛОВ ПРИ РАКЕ МОЛОЧНОЙ ЖЕЛЕЗЫ МЕТОДОМ МАСС-СПЕКТРОМЕТРИИ}

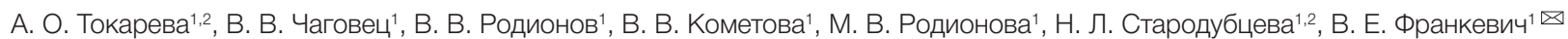 \\ ${ }^{1}$ Национальный медицинский исследовательский центр акушерства, гинекологии и перинатологии имени В. И. Кулакова, Москва, Россия \\ 2 Институт энергетических проблем химической физики имени В. Л. Тальрозе, Москва, Россия
}

\begin{abstract}
Ранняя диагностика процесса метастазирования позволяет выбрать оптимальный протокол лечения и повысить выживаемость пациенток. Неинвазивные и малоинвазивные методы диагностики помогают ставить диагноз с минимальным ущербом для организма. Целью исследования было найти биомаркеры, характеризующие начало метастатического процесса и создать диагностическую модель по липидному профилю плазмы крови с использованием жидкостной хромато-масс-спектрометрии. Исследовали плазму крови 55 пациенток, у 28 из которых было диагностировано метастазирование в региональные лимфоузлы, 27 пациенток составили контрольную группу. Липиды, относящиеся к окисленным липидам и сфингомиелинам имели при метастазировании статистически значимо более высокий и более низкий уровни соответственно. С использованием методов многомерного анализа были составлены панели липидов, и модели на их основе в ходе кросс-валидации по отдельному объекту имели чувствительность и специфичность 79 и 74\% (режим положительных ионов) и 50 и 85\% (режим отрицательных ионов).
\end{abstract}

Ключевые слова: липиды, регионарное метастазирование, рак молочной железы, плазма крови, молекулярные маркерь

Финансирование: работа выполнена при финансовой поддержке РФФИ и ГФЕН в рамках научного проекта № 19-515-55021

Соблюдение этических стандартов: исследование одобрено этическим комитетом НМИЦ АГП им. В. И. Кулакова (протокол № 9 от 22 ноября 2018 г.), проведено в соответствии с требованиями Хельсинкской декларации, Международной конференции по гармонизации (ICF), Стандартов надлежащей клинической практики (GCP), Ф3 № 323-Ф3 от 21 ноября 2011 г. «Об основах охраны здоровья граждан в Российской Федерации»; все пациентки подписали добровольное информированное согласие на участие в исследовании.

$\checkmark$ Для корреспонденции: Владимир Евгеньевич Франкевич ул. Опарина, д. 4, г. Москва, 117997, Россия; vfrankevich@gmail.com

Статья получена: 26.10.2021 Статья принята к печати: 08.11.2021 Опубликована онлайн: 10.11.2021

DOI: 10.24075/vrgmu.2021.053

The spread of cancer cells throughout the body from the primary tumor occurs through the biofluids, such as blood and lymph [1]. Axillary lymph node dissection and sentinel lymph node biopsy make it possible to define the onset of the regional lymph nodes metastasis with $100 \%$ accuracy. However, the risk of complications associated with the build-up of lymph in the tissues is high due to high invasiveness of the procedures $[2,3]$. The noninvasive techniques for diagnosis of regional metastasis are as follows: ultrasound imaging, magnetic resonance imaging and positron emission tomography (MRI and PET). Ultrasound imaging is a standard technique used to search for the regional lymph node metastases, however, the method sensitivity and specificity depend on the equipment quality and the operator's experience [4]. The use of MRI is limited by contraindications in people with kidney failure, allergy, and artificial cardiac pacemakers. PET has low sensitivity in assessment of axillary lymph node status [5].

Analysis of blood plasma is a minimally invasive method. The method may be used for diagnosis of Alzheimer's disease [6], cervical cancer [7], lung cancer [8], and cystic fibrosis affecting liver and the lungs [9] based on the plasma molecular profile. Furthermore, the protein markers of metastasis in colorectal cancer [10] and oral cancer [11] have been found in blood plasma, along with the markers of regional metastasis, 
Table 1. Relative intensities (arbitrary units) of lipids, showing significant differences in plasma in the presence or absence of metastases, in the positive ion mode

\begin{tabular}{|l|c|c|c|}
\hline \multicolumn{1}{|c|}{ Lipids } & Metastasis & No metastasis & $p$ \\
\hline OxTG 16:0_16:0_18:3(OO) & $6.86 \times 10^{5}\left(4.46 \times 10^{5} ; 8.94 \times 10^{5}\right)$ & $5.00 \times 10^{5}\left(2.43 \times 10^{5} ; 6.39 \times 10^{6}\right)$ & 0.04 \\
\hline OxTG 16:0_18:0_18:3(OH) & $1.96 \times 10^{6}\left(4.77 \times 10^{5} ; 2.42 \times 10^{6}\right)$ & $4.63 \times 10^{5}\left(3.27 \times 10^{5} ; 9.94 \times 10^{5}\right)$ & 0.003 \\
\hline OxTG 18:1_18:1_18:2(OOH) & $2.72 \times 10^{6}\left(1.70 \times 10^{6} ; 3.72 \times 10^{6}\right)$ & $1.86 \times 10^{6}\left(1.27 \times 10^{6} ; 2.50 \times 10^{6}\right)$ & 0.03 \\
\hline TG 14:0_16:0_18:1 & $2.43 \times 10^{6}\left(2.05 \times 10^{6} ; 2.84 \times 10^{6}\right)$ & $1.85 \times 10^{6}\left(1.45 \times 10^{6} ; 2.57 \times 10^{6}\right)$ & 0.04 \\
\hline
\end{tabular}

Table 2. Relative intensities (conventional units) of lipids, showing significant differences in plasma in the presence or absence of metastases, in the negative ion mode

\begin{tabular}{|l|l|l|c|}
\hline \multicolumn{1}{|c|}{ Lipids } & Metastasis & No metastasis & $p$ \\
\hline OxPC 16:0_18:2(2O) & $4.66 \times 10^{5}\left(3.35 \times 10^{5} ; 8.20 \times 10^{5}\right)$ & $2.58 \times 10^{5}\left(1.42 \times 10^{5} ; 5.22 \times 10^{5}\right)$ & 0.02 \\
\hline OxPC 16:0_22:5(OH) & $1.15 \times 10^{5}\left(8.32 \times 10^{4} ; 1.39 \times 10^{5}\right)$ & $7.93 \times 10^{4}\left(5.10 \times 10^{4} ; 1.10 \times 10^{5}\right)$ & 0.04 \\
\hline OxPC 18:0_18:2(OOH) & $1.99 \times 10^{5}\left(1.41 \times 10^{5} ; 3.81 \times 10^{5}\right)$ & $1.08 \times 10^{5}\left(6.15 \times 10^{4} ; 2.02 \times 10^{5}\right)$ & 0.008 \\
\hline OxPC 18:0_20:4(2O) & $1.31 \times 10^{5}\left(8.47 \times 10^{4} ; 2.14 \times 10^{5}\right)$ & $7.08 \times 10^{4}\left(5.21 \times 10^{4} ; 1.66 \times 10^{5}\right)$ & 0.04 \\
\hline SM d22:0/20:3 & $5.71 \times 10^{6}\left(5.17 \times 10^{6} ; 6.49 \times 10^{6}\right)$ & $6.94 \times 10^{6}\left(5.28 \times 10^{6} ; 7.38 \times 10^{6}\right)$ & 0.01 \\
\hline SM d22:0/20:4 & $4.21 \times 10^{5}\left(3.56 \times 10^{5} ; 4.90 \times 10^{5}\right)$ & $4.76 \times 10^{5}\left(4.08 \times 10^{5} ; 5.45 \times 10^{5}\right)$ & \\
\hline
\end{tabular}

however, the biomarker panel has been specific for the cancer type (lobular or ductal) [12]. Lipids, being a part of the molecular profile, are involved in important metabolic pathways [13]. The plasma lipid profile, obtained by high performance liquid chromatography-mass spectrometry, has made it possible to build an effective classification model for breast cancer and benign breast lesions based on the selected markers [14], which, combined with the listed above examples, allows one to assume the presence of metastasis markers in blood plasma.

The study was aimed to search for lipid markers of regional metastasis in blood plasma of patients with confirmed breast cancer by liquid chromatography-mass spectrometry, and to assess the possibility of creating the diagnostic panel.

\section{METHODS}

A total of 55 women diagnosed with breast cancer, who were treated in the Kulakov National Medical Research Center for Obstetrics, Gynecology and Perinatology (Russia), were enrolled. Inclusion criteria: submitted informed consent to surgery and enrollment in the study, age 18-80 years; diagnosis of breast cancer confirmed by cytological or histological findings. Exclusion criteria: neoadjuvant therapy and the presence of malignant neoplasms of other localization before the breast cancer diagnosis. The regional lymph node metastases were revealed in 28 women, and the control group comprised 27 women. Lipids were extracted from $40 \mu \mathrm{L}$ of plasma by the Folch method [15]: $480 \mu \mathrm{L}$ of $\mathrm{CHCl}_{3} / \mathrm{MeOH}$ (1/1) were added to $40 \mu \mathrm{L}$ of plasma and $5 \mu \mathrm{L}$ of the internal standard, and soaked in the ultrasonic bath for $10 \mathrm{~min}$. Then the mixture was stirred for $10 \mathrm{~s}$ and centrifuged for $5 \mathrm{~min}$ at $15,000 \mathrm{G}$. The organic phase containing lipids was collected in the separate vial. The water phase was mixed with $250 \mu \mathrm{L}$ of $\mathrm{CHCl}_{3} / \mathrm{MeOH}(1 / 1)$ and centrifuged for 5 min at 15,000 G. The lower organic phase was collected again and mixed with the previously collected sample. The lipid solution was dried in a stream of nitrogen and redissolved in $200 \mu \mathrm{L}$ of IPA / ACN $(1 / 1)$ for further analysis.

The extracted lipids were analyzed using the Dionex UltiMate 3000 liquid chromatography system (Thermo Scientific; Germany), coupled with the Maxis Impact qTOF mass spectrometer, equipped with the ESI ion source (Bruker Daltonics; Germany). The samples were separated by reversed phase chromatography using the Zorbax C18 column $(150 \times$ $2.1 \mathrm{~mm}, 5 \mu \mathrm{m}$; Agilent, USA) with linear gradient from 30 to $90 \%$ of eluent B (solution of acetonitrile / isopropanol / water in a ratio of $90 / 8 / 2$ by volume with the addition of $0.1 \%$ formic acid and $10 \mathrm{mmol} / \mathrm{L}$ ammonium formate) for $20 \mathrm{~min}$. The solution of acetonitrile / water in a ratio of 60 / 40 by volume with the addition of $0.1 \%$ formic acid and $10 \mathrm{mmol} / \mathrm{L}$ ammonium formate was used as eluent $A$. The eluent flow rate was $40 \mu \mathrm{L} / \mathrm{min}$, and the sample injection volume was $3 \mu \mathrm{L}$. Mass spectra were acquired in the positive and negative ion mode in the $\mathrm{m} / \mathrm{z}$ range of $100-1700$ using the following settings: capillary voltage $4.1 \mathrm{kV}$ and $3.0 \mathrm{kV}$ for the positive and negative ion mode; nebulizer gas pressure 0.7 bar; drying gas flow rate $6 \mathrm{~L} /$ min, drying gas temperature $200 \mathrm{oC}$.

Lipids were identified using the Lipid Match R script [16] based on the exact mass and the characteristic tandem mass spectra (MS / MS).
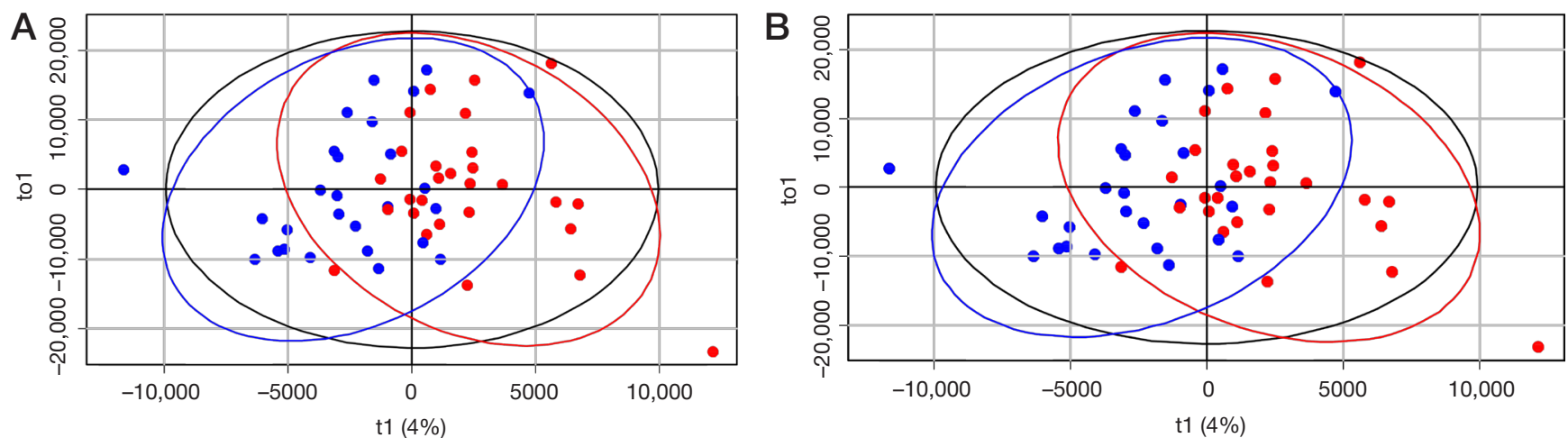

Fig. 1. Graphs of counts made for orthogonal projections to latent structures in the positive ion mode (A) and in the negative ion mode (B). The samples obtained from patients with regional metastases are marked with red dots, and the samples obtained from patients with no metastasis are marked with blue dots 
Table 3. Compounds used to build the logistic regression model, $\beta$ coefficients (conventional units), confidence interval (Cl) for $\beta$ coefficients (conventional units), Wald test, likelihood that coefficient $p$ differs from zero in the positive ion mode

\begin{tabular}{|l|c|c|c|c|}
\hline \multicolumn{1}{|c|}{ Lipids } & $\beta$ & $\mathrm{Cl} \beta$ & Wald test & $p$ \\
\hline Intercept term & -3.98 & $-15.96-6.27$ & -0.74 & 0.46 \\
\hline CE 20:4 & $3.44 \times 10^{-7}$ & $1.30 \times 10^{-7}-6.54 \times 10^{-7}$ & 2.64 & 0.008 \\
\hline LPC 18:2 & $2.37 \times 10^{-7}$ & $7.21 \times 10^{-8}-4.72 \times 10^{-7}$ & 2.44 & 0.01 \\
\hline OxTG 16:0_18:0_18:3(OH) & $1.56 \times 10^{-6}$ & $6.37 \times 10^{-7}-2.89 \times 10^{-6}$ & 2.83 & 0.005 \\
\hline PC 16:0_22:5 & $2.66 \times 10^{-7}$ & $1.09 \times 10^{-7}-5.17 \times 10^{-7}$ & 2.55 & 0.01 \\
\hline SM d18:2/24:1 & $-4.72 \times 10^{-7}$ & $-9.01 \times 10^{-7}-1.70 \times 10^{-7}$ & -2.60 & 0.009 \\
\hline SM d18:1/24:0 & $-3.92 \times 10^{-7}$ & $-8.47 \times 10^{-7}-1.25 \times 10^{-7}$ & -2.26 & 0.02 \\
\hline SM d18:1/22:0 & $3.85 \times 10^{-7}$ & $6.70 \times 10^{-8}-8.51 \times 10^{-7}$ & 2.01 & 0.04 \\
\hline
\end{tabular}

Table 4. Compounds used to build the logistic regression model, $\beta$ coefficients (conventional units), confidence interval (Cl) for $\beta$ coefficients (conventional units), Wald test, likelihood that coefficient $p$ differs from zero in the negative ion mode

\begin{tabular}{|l|c|c|c|c|}
\hline \multicolumn{1}{|c|}{ Lipids } & $\beta$ & Cl $\beta$ & Wald test & $p$ \\
\hline Intercept term & 3.71 & $-1.28-9.09$ & 1.43 & 0.15 \\
\hline PC 16:0_22:5 & $4.89^{*} 10^{-7}$ & $1.37^{*} 10^{-7}-9.45^{*} 10^{-7}$ & 2.40 & 0.02 \\
\hline SM d22:0/20:3 & $-1.05^{*} 10^{-6}$ & $-1.98^{*} 10^{-6}-2.52^{*} 10^{-7}$ & -2.42 & 0.02 \\
\hline
\end{tabular}

Statistical processing of the results was performed using $R$ scripts [17] in the Rstudio environment [18].

The search for compounds, showing significant differences in plasma levels in patients with metastases and patients with no metastases, was performed using the Mann-Whitney U-test for pairwise comparison of groups. Median (Me) and quartiles $Q_{1}$ and $Q_{3}$ were used to describe the quantitative data. The significance threshold was set at $p=0.05$.

The diagnostic model based on logistic regression was built by calculating the projection of the variable using the orthogonal projection to latent structures solution [19] and selecting the compounds with the variable projection value exceeding 1 . The variables were selected from the selected variables using the step-by-step approach based on the Akaike information criterion (AIC) [20] until this led to the decrease in AIC. To build the final model, the variables, the coefficients of which were not significantly different from $0(p>0.05)$, were removed from the regression in a step-by-step manner. The quality of the resulting diagnostic model was tested by leave-one-out crossvalidation. Area under the ROC curve, sensitivity and specificity were used for assessment.

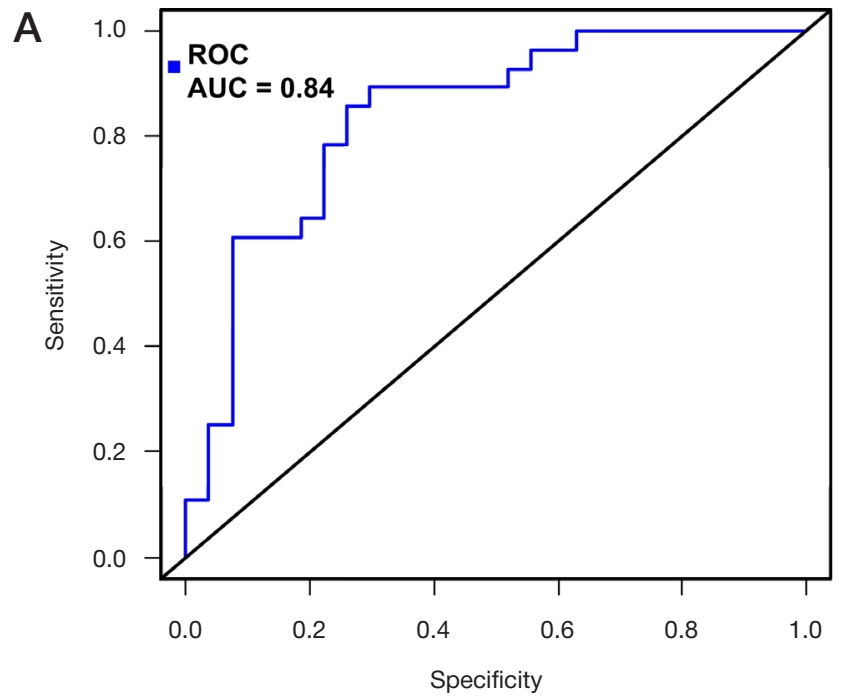

RESULTS

During the study, we identified 183 lipid compounds in the positive ion mode and 161 compounds in the negative ion mode. Of those, four compounds showed significant differences in their levels in the positive ion mode (Table 1), and six compounds showed significant differences in the negative ion mode (Table 2). The levels of oxylipins (oxo-triglycerides in the positive ion mode and oxo-phosphotidylcholines in the negative ion mode) increased in case of metastasis. The levels of sphingomyelins, on the contrary, decreased in the presence of metastases.

Based on the constructed orthogonal projections to latent structures (Fig. 1), we selected 36 lipids in the positive ion mode and 29 lipids in the negative ion mode with the variable projection (VP) value exceeding 1 .

We used seven compounds in the positive ion mode, which allowed us to build a model with the area under the ROC curve of 0.84 (Table 3; Fig. 2A), and two compounds in the negative ion mode, allowing us to build a model with the area under the ROC curve of 0.71 (Table 4; Fig. 2B). Sensitivity and specificity

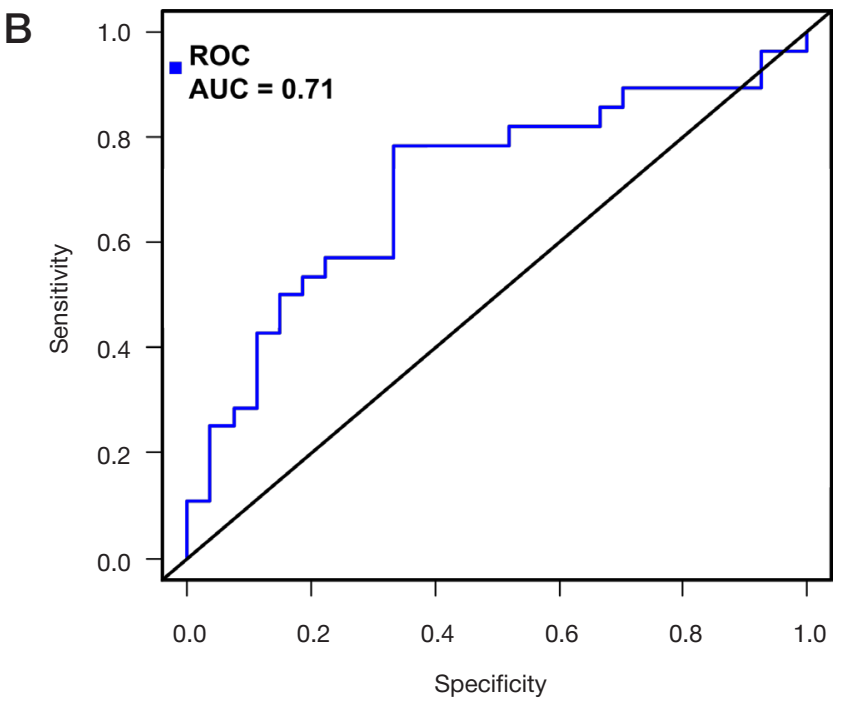

Fig. 2. ROC curve plotted during cross-validation of the diagnostic model in the positive ion mode (A) and negative ion mode (B) 
of the model in the positive ion mode were 79 and $74 \%$, respectively, and these indicators of the model in the negative ion mode were 50 and $85 \%$, respectively.

\section{DISCUSSION}

Most of the lipids, the levels of significantly increase in case of metastasis, are the oxidized lipids. The oxidized lipids are formed primarily in the apoptotic cells. Furthermore, the oxidized lipids are involved in inflammation [21]. These have been also isolated as the predictors of coronary heart disease in blood plasma [22]. The panels created comprise mostly sphingomyelins together with lyso- and phosphotidylcholines, containing long acyl chains. The association of fatty acid synthases and omega- 6 polyunsaturated fatty acids with metastasis is known today [23, 24], and elevated levels of sphingomyelins and lysophosphotidylcholines in relation to phosphotidylcholines have been registered in mice's plasma with advanced metastatic breast cancer [25]. However, in this study, the significantly decreased levels of sphingomyelins upon the onset of metastasis were observed in plasma. The varying changes in the sphingomyelin levels upon the onset of metastasis were revealed during the analysis of malignant tissue (decreased levels) and the nearby normal breast tissue (increased levels)
[26]. Of the lipids, grouped together into the diagnostic panel, only two compounds show significant differences in their levels in the presence or absence of metastases. This is because the diagnostic panel has been created using multivariate analysis taking into account the associations between lipids. The use of this method for marker selection is justifiable in terms of applying the model to a multi-component space with nonorthogonal components, such as blood lipid profile. The use of univariate analysis methods makes it possible to assess the lipid profile changes with respect to the further investigation of metastatic process pathophysiology.

\section{CONCLUSIONS}

This study analyzed the lipid profile of patients with breast cancer using high-performance liquid chromatography-mass spectrometry. The lipids, showing significant differences in their levels, were the oxidized lipids and sphingomyelins. The lipids, included in the diagnostic panels, belonged mostly to the classes of sphingomyelins and phosphotidylcholines, and were characterized by increased unsaturation of acyl chains and the length of 20-24 carbon atoms. The diagnostic model obtained may be used for further research focused on developing the method for minimally invasive diagnosis of metastasis.

\section{References}

1. Fidler IJ. The pathogenesis of cancer metastasis: the 'seed and soil' hypothesis revisited. Nat Rev Cancer. 2003; 3 (6): 453-8.

2. Silberman AW, McVay C, Cohen JS, Altura JF, Brackert S, Sarna GP, et al. Comparative Morbidity of Axillary Lymph Node Dissection and the Sentinel Lymph Node Technique. Ann Surg. 2004; 240 (1): 1-6.

3. Schrenk P, Rieger R, Shamiyeh A, Wayand W. Morbidity following sentinel lymph node biopsy versus axillary lymph node dissection for patients with breast carcinoma. Cancer. 2000; 88 (3): 608-14.

4. Sukhikh GT, Sencha AN. Multiparametric ultrasound diagnosis of breast diseases. Cham: Springer, 2018.

5. Zhou M, Lu B, Lv G, Tang Q, Zhu J, Li J, et al. Differential diagnosis between metastatic and non-metastatic lymph nodes using DWMRI: a meta-analysis of diagnostic accuracy studies. J Cancer Res Clin Oncol. 2015; 141 (6): 1119-30.

6. Wang T, Xiao S, Liu Y, Lin Z, Su N, Li X, et al. The efficacy of plasma biomarkers in early diagnosis of Alzheimer's disease. Int $J$ Geriatr Psychiatry. 2014; 29 (7): 713-9.

7. Lin YW, Lai HC, Lin CY, Chiou JY, Shui HA, Chang CC, et al. Plasma proteomic profiling for detecting and differentiating in situ and invasive carcinomas of the uterine cervix. Int J Gynecol Cancer. 2006; 16 (3): 1216-24.

8. Zhong L, Coe SP, Stromberg AJ, Khattar NH, Jett JR, Hirschowitz EA. Profiling tumor-associated antibodies for early detection of nonsmall cell lung cancer. J Thorac Oncol. 2006; 1 (6): 513-9.

9. Schwarz KB, Rosensweig J, Sharma S, Jones L, Durant M, Potter C, et al. Plasma markers of platelet activation in cystic fibrosis liver and lung disease. J Pediatr Gastroenterol Nutr. 2003; 37 (2): 187-91.

10. Langenskiöld M, Holmdahl L, Falk P, Ivarsson ML. Increased plasma MMP-2 protein expression in lymph node-positive patients with colorectal cancer. Int J Colorectal Dis. 2005; 20 (3): 245-52.

11. Chai YD, Zhang L, Yang Y, Su T. Discovery of potential serum protein biomarkers for lymph-node metastasis in oral cancer. Head Neck. 2015; 38 (1): 118-25.

12. Yigitbasi T, Calibasi-Kocal G, Buyukuslu N, Kemal Atahan M, Kupeli H, Yigit S, et al. SELDI-TOF-MS Profiling of Metastatic Phenotype in Histopathological Subtypes of Breast Cancer. Curr Proteomics. 2018; 15 (3): 214-20.

13. Bandu R, Mok HJ, Kim KP. Phospholipids as cancer biomarkers: mass spectrometry-based analysis. Mass Spectrom Rev. 2016; 47 (3): $1-32$.

14. Chen X, Chen H, Dai M, Ai J, Li Y, Mahon B, et al. Plasma lipidomics profiling identified lipid biomarkers in distinguishing early-stage breast cancer from benign lesions. Oncotarget. 2016; 7 (24): 36622-31.

15. Folch J, Lees M, Sloane Stanley GH. A simple method for the isolation and purification of total lipides from animal tissues. J Biol Chem. 1957; 226 (1): 497-509.

16. Koelmel JP, Kroeger NM, Ulmer CZ, Bowden JA, Patterson RE, Cochran JA, et al. LipidMatch: An automated workflow for rulebased lipid identification using untargeted high-resolution tandem mass spectrometry data. BMC Bioinformatics. 2017; 18 (1): $1-11$

17. R Development Core Team. A Language and Environment for Statistical Computing. R Found Stat Comput. 2019.

18. R team. R Studio: Integrated Development for R. 2016.

19. Galindo-Prieto B, Eriksson L, Trygg J. Variable influence on projection (VIP) for OPLS models and its applicability in multivariate time series analysis. Chemom Intell Lab Syst. 2015; 146: 297-304.

20. Akaike H. A New Look at the Statistical Model Identification. IEEE Trans Automat Contr. 1974; 19 (6): 716-23.

21. Miller YI, Shyy JYJ. Context-Dependent Role of Oxidized Lipids and Lipoproteins in Inflammation. Trends Endocrinol Metab. 2017; 28 (2): 143-52.

22. Paynter NP, Balasubramanian R, Giulianini F, Wang DD, Tinker LF, Gopal S etc. Metabolic predictors of incident coronary heart disease in women. Circulation. 2018; 137 (8): 841-53.

23. Ferreri $\mathrm{C}$, Sansone A, Ferreri R, Amézaga J, Tueros I. Fatty acids and membrane lipidomics in oncology: A cross-road of nutritional, signaling and metabolic pathways. Metabolites. 2020; 10 (9): $1-26$.

24. Maan M, Peters JM, Dutta M, Patterson AD. Lipid metabolism and lipophagy in cancer. Biochem Biophys Res Commun. 2018; 504 (3): 582-9

25. Kus K, Kij A, Zakrzewska A, Jasztal A, Stojak M, Walczak M, et al. Alterations in arginine and energy metabolism, structural and signalling lipids in metastatic breast cancer in mice detected in plasma by targeted metabolomics and lipidomics. Breast Cancer 
Res. 2018; 20 (1): 1-13.

26. Tokareva AO, Chagovets VV, Rodionov VV, Kometova VV, Rodionova MV, Starodubtseva NL, i dr. Lipidnye markery

\section{Литература}

1. Fidler IJ. The pathogenesis of cancer metastasis: the 'seed and soil' hypothesis revisited. Nat Rev Cancer. 2003; 3 (6): 453-8.

2. Silberman AW, McVay C, Cohen JS, Altura JF, Brackert S, Sarna GP, et al. Comparative Morbidity of Axillary Lymph Node Dissection and the Sentinel Lymph Node Technique. Ann Surg. 2004; 240 (1): 1-6.

3. Schrenk P, Rieger R, Shamiyeh A, Wayand W. Morbidity following sentinel lymph node biopsy versus axillary lymph node dissection for patients with breast carcinoma. Cancer. 2000; 88 (3): 608-14.

4. Sukhikh GT, Sencha AN. Multiparametric ultrasound diagnosis of breast diseases. Cham: Springer, 2018.

5. Zhou M, Lu B, Lv G, Tang Q, Zhu J, Li J, et al. Differential diagnosis between metastatic and non-metastatic lymph nodes using DWMRI: a meta-analysis of diagnostic accuracy studies. J Cancer Res Clin Oncol. 2015; 141 (6): 1119-30.

6. Wang T, Xiao S, Liu Y, Lin Z, Su N, Li X, et al. The efficacy of plasma biomarkers in early diagnosis of Alzheimer's disease. Int $\mathrm{J}$ Geriatr Psychiatry. 2014; 29 (7): 713-9.

7. Lin YW, Lai HC, Lin CY, Chiou JY, Shui HA, Chang CC, et al. Plasma proteomic profiling for detecting and differentiating in situ and invasive carcinomas of the uterine cervix. Int J Gynecol Cancer. 2006; 16 (3): 1216-24.

8. Zhong L, Coe SP, Stromberg AJ, Khattar NH, Jett JR, Hirschowitz EA. Profiling tumor-associated antibodies for early detection of nonsmall cell lung cancer. J Thorac Oncol. 2006; 1 (6): 513-9.

9. Schwarz KB, Rosensweig J, Sharma S, Jones L, Durant M, Potter C, et al. Plasma markers of platelet activation in cystic fibrosis liver and lung disease. J Pediatr Gastroenterol Nutr. 2003; 37 (2): 187-91.

10. Langenskiöld M, Holmdahl L, Falk P, Ivarsson ML. Increased plasma MMP-2 protein expression in lymph node-positive patients with colorectal cancer. Int J Colorectal Dis. 2005; 20 (3): 245-52.

11. Chai $Y D$, Zhang L, Yang $Y$, Su T. Discovery of potential serum protein biomarkers for lymph-node metastasis in oral cancer. Head Neck. 2015; 38 (1): 118-25.

12. Yigitbasi T, Calibasi-Kocal G, Buyukuslu N, Kemal Atahan M, Kupeli H, Yigit S, et al. SELDI-TOF-MS Profiling of Metastatic Phenotype in Histopathological Subtypes of Breast Cancer. Curr Proteomics. 2018; 15 (3): 214-20.

13. Bandu R, Mok HJ, Kim KP. Phospholipids as cancer biomarkers: mass spectrometry-based analysis. Mass Spectrom Rev. 2016; 47 (3): 1-32.

14. Chen X, Chen H, Dai M, Ai J, Li Y, Mahon B, et al. Plasma metastaticheskogo porazhenija regionarnyh limfouzlov u bol'nyh rakom molochnoj zhelezy. Akusherstvo i ginekologija. 2020; 8: 133-40. Russia.

lipidomics profiling identified lipid biomarkers in distinguishing early-stage breast cancer from benign lesions. Oncotarget. 2016; 7 (24): 36622-31.

15. Folch J, Lees M, Sloane Stanley GH. A simple method for the isolation and purification of total lipides from animal tissues. J Biol Chem. 1957; 226 (1): 497-509.

16. Koelmel JP, Kroeger NM, Ulmer CZ, Bowden JA, Patterson RE, Cochran JA, et al. LipidMatch: An automated workflow for rulebased lipid identification using untargeted high-resolution tandem mass spectrometry data. BMC Bioinformatics. 2017; 18 (1): $1-11$.

17. R Development Core Team. A Language and Environment for Statistical Computing. R Found Stat Comput. 2019.

18. R team. R Studio: Integrated Development for R. 2016.

19. Galindo-Prieto B, Eriksson L, Trygg J. Variable influence on projection (VIP) for OPLS models and its applicability in multivariate time series analysis. Chemom Intell Lab Syst. 2015; 146: 297-304.

20. Akaike H. A New Look at the Statistical Model Identification. IEEE Trans Automat Contr. 1974; 19 (6): 716-23.

21. Miller YI, Shyy JYJ. Context-Dependent Role of Oxidized Lipids and Lipoproteins in Inflammation. Trends Endocrinol Metab. 2017; 28 (2): 143-52.

22. Paynter NP, Balasubramanian R, Giulianini F, Wang DD, Tinker LF, Gopal S etc. Metabolic predictors of incident coronary heart disease in women. Circulation. 2018; 137 (8): 841-53.

23. Ferreri C, Sansone A, Ferreri R, Amézaga J, Tueros I. Fatty acids and membrane lipidomics in oncology: A cross-road of nutritional, signaling and metabolic pathways. Metabolites. 2020; 10 (9): $1-26$.

24. Maan M, Peters JM, Dutta M, Patterson AD. Lipid metabolism and lipophagy in cancer. Biochem Biophys Res Commun. 2018; 504 (3): 582-9.

25. Kus K, Kij A, Zakrzewska A, Jasztal A, Stojak M, Walczak M, et al. Alterations in arginine and energy metabolism, structural and signalling lipids in metastatic breast cancer in mice detected in plasma by targeted metabolomics and lipidomics. Breast Cancer Res. 2018; 20 (1): 1-13.

26. Токарева А. О., Чаговец В. В., Родионов В. В., Кометова В. В., Родионова М. В., Стародубцева Н. Л. и др. Липидные маркеры метастатического поражения регионарных лимфоузлов у больных раком молочной железы. Акушерство и гинекология. 2020; 8: 133-40. 